\title{
Two Styles of Mental Functioning and Literary Language: A Phenomenological Psychological Reading of A. Machado and C. Cavafy. A tribute to Zena Helman
}

\author{
Latife Yazigi $^{1}$ \\ Universidade Federal de São Paulo
}

\begin{abstract}
RESUMO - A autora apresenta uma analise comparativa de alguns poemas de Antonio Machado e Constatino Cavafy seguindo a abordagem psicológica fenomenológica de Minkowska. Essa análise fenomenológica identifica dois estilos de funcionamento mental - sensorial e racional. $\mathrm{O}$ estilo sensorial se caracteriza pela adesividade - adesividade a tudo que tem vida, à experiencia concreta, ao ambiente e à ação. O estilo racional é dominado pela abstração e pensamento simbólico, isolamento e distância, imobilização e cisão, e por um contato menos vital com a realidade. A análise fenomenológica comparativa de alguns poemas de A. Machado e C. Cavafy revela Machado como um poeta sensorial e impressionista e Cavafy como um poeta do isolamento e da abstração impessoal.
\end{abstract}

Palavras-chave: abordagem fenomenológica; poemas; Antonio Machado; Constatino Cavafy.

\begin{abstract}
Following Minkowska's psychological phenomenological approach, a comparative analysis of some poems of Antonio Machado and Constantine Cavafy was carried out. This phenomenological analysis identifies two styles of mental functioning - sensorial and rational. The sensorial style is characterized by adhesiveness - adhesiveness to all that has life, to concrete experience, to surroundings, and to action. The rational style is dominated by abstraction and symbolic thinking, isolation and distance, immobilization and splitting, and less vital contact with reality. A phenomenological comparative analysis of some of Machado and Cavafy poems reveals Machado as a sensorial and impressionistic poet and Cavafy as a poet of isolation and impersonality abstraction.
\end{abstract}

Key words: Antonio Machado; Constatino Cavafy; poems; phenomenological approach.

\section{The structural phenomenology}

The study of creative expression, according to Minkowska's psychological phenomenological proposal, had encouraged us to carry on a comparative analysis of some poems of Antonio Machado and Constantine Cavafy.

In 1949 Minkowska published De Van Gogh et Seurat aux Dessins d'Enfants: A la recherche du monde des formes - Rorschach, a psychological study on the relation between drawing, painting and personality structure. She introduces the phenomenological analysis of graphic expression, 'the world of forms', in a psychopathological perspective, identifying two poles of mental functioning - sensorial and rational. Therefore, in Van Gogh's paintings everything is feeling and movement, coloring is intense, lines are drawn in strong hatchings, which rise and fall, swirl and twist. 'Rising and falling' stands out as an essential and persistent phenomenon in this mode of vision, as tells us Helman (1984, p. 14). In opposition, Seurat, the rational painter and his carefully elaborate work always searches for geometrical precision of forms and static features, where distance and cold colors prevail.

As to his personality, the sensorial person has a more concrete and animated type of vision, with an affectivity

1 Endereço: Correspondence pertaining to this article should be addressed to Latife Yazigi, Escola Paulista de Medicina, Universidade Federal de São Paulo - Departamento de Psiquiatria - Rua Botucatu, 740, São Paulo, SP, Brasil, 04023-0900

E-mail: yazigi@psiquiatria.epm.br deep-rooted and closely linked to his surroundings, thus attaching him firmly to his group. On the intellectual plane, he functions at a slower pace, pausing on details, consequently losing the overall view.

The manner of approach of the rational person is that of an abstract nature of the whole, with a static and rigid quality. Distance and withdrawal from others mark his affective relations, where less interest and symbolism predominate "He thinks rather than sees" as Helman (1984, p.15) defines him.

Therefore, according to this phenomenological structural approach, the sensorial style is characterized by adhesiveness - adhesiveness to all that has life, to concrete experience, to surroundings, and to action. The rational style is dominated by abstraction and symbolic thinking, isolation and distance, immobilization and splitting, and less vital contact with reality.

Minkowska's essay generated prolific ramifications on other domains of creativity, such as Ganidel's (1960) contributions to the literary language with his comparative study on Flaubert's and Giraudoux's opposite styles, and Rispal's (1962) paper on Lautréamont.

According to Ganidel (1960), it is possible to identify in all artistic productions these two ways of perceiving, translating, and experiencing the world. They represent two possibilities of the thinking process: an immediate one where the decisive time is that of sensation, and a mediatory one founded on the speculative time. The opposition between the sensorial and rational worlds can thus be expressed by the following dichotomies: horizontality versus verticality; 
mobility versus immobility; sinuosity versus straightness; joining-up versus splitting-up; subordinate or coordinate clauses versus short and precise clauses; verbs versus abstract nouns; imagery vision versus reasoning; sensation versus ideas; metaphor versus symbolism.

Therefore, in the sensorial style the image is full of motion and relationship, and is born from emotion - emotion somewhat lived or experienced, emotion that escapes from the intellectual or rational elaboration. The vivid vision invites us to participate in the scene. Sometimes, the images are entangled as in a dream, but the fantastic is not felt as strange and the non-real becomes incarnate. The loops on sinuous lines in their movement join the objects. The movements can be expressed by animation as well as by inanimation; ascending and descending movements that can all be assembled. The importance of movements is shown in the verbs - verbs that sustain the clause. The juxtaposition of small concrete details assures the progression of the clause - juxtaposition that expresses itself by 'with', 'and', 'between', 'on', 'in', 'below', 'above', among others. The pictures are colorful and impressionistic in a sensorial way, and its richness comes from the abundance of details linked in a composition. Houses, fields, and trees, with their vivid colors, compose the landscape. The scene generates an ambiance and an atmosphere that immediately evoke the emotion and wake it up. The images are of value in themselves not in their significations. The characters are not limited to themselves, but they are rather the expression of a more vivid image than themselves, and they behave as agents of the action (Ganidel, 1960).

In the rational organization of the thinking process everything is constructed from symbols, symmetries and global visions. The attendance time is consecrated to meditation, speculation and to the mind operation that transposes, compares, establishes a rapport, an analogy. Sensation here plays a secondary role, since the idea is dominant; there are no pure sensations but idea-sensations. The experience of the encounter is withdrawn from the time, the action is isolated in the past, the characters of another time appear invested with a signification. The relationship contact is done through a dispossession of himself. The characters do not have a face, the real is discarnate, those that are not present are mentioned, the absent or the dead are evoked - they become characters. The scenery is static, composed by geometric figures. The expressions are symmetric and give a scanted rhythm to the clause. The thought is rigorously elaborated, and everything is built viewing perfection (Ganidel, 1960).

\section{The poets}

Antonio Machado himself tells us: "I was born in Seville a night in July, 1875, in the famous mansion of Las Dueñas located on the street of the same name. The memories that I have of my native town are those of a child, because at the age of eight I left for Madrid, where my parents took residence and where I pursued my studies at the 'Instituición
Libre de Enseñanza'. I have kept a lively affection and a deep gratitude for my teachers. My adolescence and my youth were Madridians. I travel throughout France and Spain. In 1907, I became professor of French at Soria, a language that I taught for five years. It was there that I married, it was there that my wife died, and the memories have accompanied me always. I left for Baeza, where I am still living today. Walking and reading are my pleasures" (1983, p. 14).

In the Prologues of Páginas Escogidas, Machado explains: "I do not have the habit of coming back to what I have done, not even re-reading what I have written, before sending it to press, which at the moment is for me the motive for a non negligible embarrassment. Upon presenting the volume of Páginas Escogidas I was forced not only to re-read, but also to select, which means to judge. Sad work! Because even if a poet makes a mistake when he produces his rhymes, he is always in agreement with himself, but as the years pass, the man that judges a work of his own is far distant from the one who has produced it. And perhaps he can be unfair with himself just as a father's love, and excess of indulgence; but sometimes out of forgetfulness, he can be ungrateful, since the written page never recalls everything he has tried, but the little he has achieved." And continues, "The sadness of returning to our own work does not come from the consciousness of the little we have obtained, but from the much we have left undone" (Ibid., p. 7).

Constantine Cavafy was born in Alexandria, Egypt, in 1863. Son of Greek parents originally from Constantinople, had dedicated to poetry since his youth. He lived in England for seven years, stayed two years in Greece, and went just once to Paris. Coming from a bourgeoisie family, he had to work after his father's death and occupied a position of simple employee for a long time, and later on as ofice chief, at the ministry of irrigation. He had also been a broker in Alexandria. He died in this same city in 1933.

During his life, Cavafy had allowed to publish just a few of his poems in magazines. Habitually, he had them published in fliers distributed to friends. He was recognized as a poet late in life. His production was almost secret until the end of his days. Cavafy had the habit of retouching his poems, which he did until his death. Even his earliest poems had the mark of later corrections. He searched perfection. "And it was just at the end of his life that he somehow openly expressed his most intimate anxieties, emotions and memories, which had always inspired and held his work" (Yourcenar, 1978, p. 8).

Yourcenar (1978) tells us about the realistic outlines of Cavafy's style - outlines almost flat due to constant search for exactitude; his arid poems where the background has found its precise tonality, but with a certain indifference to the landscape and very little mention to nature.

Foster was in contact with Cavafy in Alexandria for some years, and depicts him as "a Greek gentleman with his straw hat, standing completely immobile, in a slightly oblique position in relation to the rest of the universe" (cf. Yourcenar, 1978, p. 11). A young woman who had known the poet, describes his appearance: "his air of being similar to no one, 
his paleness, his throat involved in bandages (Cavafy died a few months later of throat cancer), his somber clothes, and his attitude, when alone, murmuring something in deep meditation. A confused murmur because the sick man was already aphonic, but which reminded me of the psalms of a wizard" (cf. Ibid., p.12).

\section{The essay}

Machado is a sensorial and impressionistic poet. Poet of the movement, the travelers, and the roads. Poet of the melodies of the waves, of the sonority of the winds and rivers; of the colors of the landscapes and fields; and of the fragrance of the flowers. Poet of the shadings of the sun and of the moon; of the clair-obscur of the lights. In his poems, the elements are intermingled, and the moments are linked, composing a lively and pulsating scenery, where everything appeals to sensations and emotions, in a rhythm that conveys musicality. Machado's compositions are like a lively fresco.

Cavafy is the poet of isolation, impersonality, due to his vague and veiled way of expressing his emotions, due to his obstinations of looking for perfection, whence his constant retouches to his poems. In these the image of the right line, of immobility, of speculative time, of reflection and symbolism predominates. The abstraction leads him to an attitude of withdrawing from everything that is immediate and experienced. There is less vitality, and the emotion is rather intellectualized than lived. Cavafy is a real example of a rational poet.

Now, let us appreciate some poems of these two authors. Machado's poems are transcripts from Roads dreamed clear afternoons. An anthology of the poetry of Antonio Machado, and translated by Carl W. Cook, and from Antonio Machado: Selected Poems, translated by Alan S. Trueblood. Cavafy's poems are from C. P. Cavafy Collected Poems, translated by Edmund Keely and Philip Sherrard.

\section{Everyday life and the passage of time}

Initially, everyday life and passage of time are themes in which distinct expressions are found in each one of them, such as Machado's Boredom and Cavafy's Monotony.

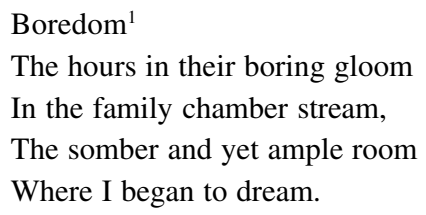

From its secluded nook the clock, In shadow clear to see,

1. Antonio Machado, Roads dreamed clear afternoons. An anthology of the poetry of Antonio Machado. Translated into English verse by Carl W. Cook. Spanish Literature Publications Company. York, South Carolina, 1994, p. 55. with its slow, rhythmical tick-tock

Goes beating odiously.

The monotony as falling spray

Of water clear does say:

One day is like another day;

Today's like yesterday.

The evening falls. The winds arouse

The faded, golden park ...

How ceaselessly have wept the boughs

All withering and dark!

\section{Monotony $^{2}$}

One monotonous day follows another

equally monotonous. The same things

will happen again, and then will happen again,

the same moments will come and go.

A month passes by and brings another month.

Easy to guess what lies ahead:

all of yesterday's boredom.

And tomorrow ends up no longer like tomorrow.

Machado treats the time flow inscribed in the quotidian repetition that leads to the boredom by long and complete clauses that compose the full verse. The 'ceaselessly' passing hours, the watch onomatopoeic 'tick-tock' cadence, 'the evening falls', and 'the winds arouse', mark the poem's rhythm. The monotony sensation is provoked by the cyclic repetition of 'one day is like another day' and 'today's like yesterday'. Reiteration that generates a tempo course that culminates with 'have wept the boughs'. Associated to the image brought by the verbs, the clair-obscur of 'somber room', the shading of 'the clock in shadow clear to see', and 'water clear', 'golden park', complete the poem generating an expressionistic atmosphere which culminates in 'faded' view. No doubt, the metaphor of the monotony is very sensorial in Machado.

Cavafy's verses, inscribed in short clauses, make us think of the poet's quotidian life, impregnated by routine immutability. Routine announced in the first verse by monotony through repetition and perpetuation of an incessant pace of 'will happen again, and then will happen again'. Moments, days, and months follow in a passing time that approaches and withdraws, that 'come and go'. The verse sequence presents itself like a procession, a straight line. It is a movement that leads to a paralysis - antitheses typically rational. The picture is of a global image, the time is that of the past and future, hence the distance from the present and the detachment from the real experience. There is no subject, but impersonality. Abstraction and symbolism dominate. We do not feel the pulsation of a live anxiety, but rather an intellectual elaboration of an anguish that communicates the deep effect

2. C. P. Cavafy, Collected Poems. Revised Edition. Translated by Edmund Keely \& Philip Sherrard; Edited by George Savidis. Princeton University Press, Princeton, New Jersey, 1992, p. 25. 
of monotony. This poem reminds us of Sisyphus and his inexorable destiny.

\section{Verbs, modifiers, amazement and hopeless}

Perhaps $^{3}$

Since on my chimera I was focusing,

Obvious to everything outside,

One day I was surprised be fertile spring,

Spring smiling in the whole broad countryside.

Green leaves were soon to spread

Among the branches with buds burgeoning,

And flowers blooming yellow, white, and red

A spot of landscape were enlivening.

And, rain of golden arrows, there the sun

Upon the branches juvenile was blazing;

Where flowed the ample river in sonorous run

The graceful poplars at themselves were gazing.

Behind me so much road, since it's the first

Time that I've really seen the spring forth burst,

I said, and then, declamatorily:

"How late it is now for my happiness!"

And later, waking on, like one to see

Wings of another illusion: Nevertheless,

One day I'll overtake my youthfulness!

Walls ${ }^{4}$

With no consideration, no pity, no shame,

they have built walls around me, thick and high.

And now I sit here feeling hopeless.

I can't think of anything else: this fate gnaws my mind-

because I had so much to do outside.

When they were building the walls, how could I not have noticed!

But I never heard the builders, not a sound.

Imperceptibly they have closed me off from the outside world.

Amazement is present in both poems. In Machado, it is the passing from the submersion in the fantasy, the 'chimera', to the fascination of the charms of the 'fertile spring', until the final drop into 'wings of another illusion' and the hope that "one day I will overtake my youthfulness". The marvel of the countryside amplitude and diversity, in an exuberant spring full of colors, brightness, movements, and sounds, is offered to the poet's delight by reality, physical existence

3. Antonio Machado, Roads dreamed clear afternoons. An anthology of the poetry of Antonio Machado. Translated into English verse by Carl W. Cook. Spanish Literature Publications Company. York, South Carolina, 1994, p. 53

4. C. P. Cavafy, Collected Poems. Revised Edition. Translated by Edmund Keely \& Philip Sherrard; Edited by George Savidis. Princeton University Press, Princeton, New Jersey, 1992, p. 3. instead of reverie. To him, fortuitousness is associated to nature's vivid and pulsating sensuality that recalls adolescent freshness. The long clauses are supported and forged mainly through the resonance of the present participles 'focusing', 'smiling', 'burgeoning', 'blooming', 'enlivening', 'blazing', 'gazing', and 'waking'. Verbs that give rise to a rhythmic motion picture. The participation of modifiers 'golden', 'juvenile', 'sonorous', and 'graceful' enhance life, color, and joy to the impressionistic image. However, this flow leads to a minute glimpse of sadness when the poet awakes and realizes that even reality can diverge him, yet he immediately recovers his faith.

In Cavafy, it is the poet's bitterness of being compelled to restrain himself in an office and renounce to his aesthetic ambitions. The poem conveys the anguish of lack of communication and confinement due to the implacable destiny that submits and takes liberty away. The scene, of being immured as in a prison, is like a photo - a back and white. Its vertical, formal, and hard lines reminds us of a cloister enclosed and isolated from the world. The formal aspect of the 'thick and high walls', and the impersonality of the subject 'they', complete the description of an objective and fatal situation that communicates the painful echo of a suffering, rather symbolic than lively and pulsating. The corrected, short, and synthetic clauses with verbs as 'think', 'notice', and nouns as 'consideration', 'mind' confirm the rational style. Also, the autistic isolation, and the withdrawal from the 'outside world' leading to a 'hopeless' and to a 'not a sound' silence point out Cavafy's intellectual style.

\section{Present participles, sorrow and melancholy}

\section{Songs XLIII}

It was a morn and April's smile was glowing.

Before the horizon touched with gold, white showing,

Opaque, the moon was dying; and afar,

Like airy fancy tenuous, was flowing

The cloud that delicately bedims a star.

Since smiling was the morning rosy glowing

I window opened to sun in East showing,

And that East penetrated my bedroom

In song of larks, in delicate perfume

Of flora early, in fountain laughter's flowing.

It was a melancholy evening gleaming.

April was smiling. I opened my windows wide

Unto the breeze ... And on the breeze was streaming

Perfumes of roses, bells that toll outside...

5. Antonio Machado Roads dreamed clear afternoons. An anthology of the poetry of Antonio Machado. Translated into English verse by Carl W. Cook. Spanish Literature Publications Company. York, South Carolina, 1994, p. 45 
Bells tolling, from afar, in weeping gloom,

So soft of roses aromatic tease ...

... Where are the gardens in which roses bloom?

What do the bells so sweet say to the breeze?

I asked the afternoon of April dying:

Does joy eventually approach my door?

The April afternoon with smile replying:

Joy passed before your door - then somber sighing:

It passed your door. It passes once, no more.

The windows ${ }^{6}$

In these dark rooms where I live out

empty days, I circle back and forth

trying to find the windows.

It will be a great relief when a window opens.

But the windows aren't there to be found-

or at least I cannot find them. And perhaps

it is better if I don't find them.

Perhaps the light will prove another tyranny.

Who knows what new things it will expose?

What different landscapes offer the windows!

In Machado we visualize a sensorial spectacle full of sounds - 'April's smile', 'song of larks', 'fountain laughter's', 'bells tolling', 'somber sighing'; and odors - 'perfume of flora', 'perfume of roses', 'roses of aromatic tease'; with less color. Rhythmic, rhyme, and sonority are bestowed by present participles 'ings', a total of fifteen. Thus, verbs and movements sustain the poem, that grant life to it - life that is also expressed in the last verse in conversation form between the poet and his poem. Time is marked all through by the ongoing from morning, afternoon, and evening, as moments flowing, ending with the bitter insight - 'joy passes once, no more'. The view encompasses 'horizon', 'East', 'moon', 'cloud', 'star', 'sun', and 'breeze' - a very rich scenery. Fragrances and aromas enhance sensuality. Nuances such as 'gold', 'white', 'opaque', 'gleaming' create a modulation a modulation of a sorrowful and nostalgic tone, but without melancholy. Affect resounds in these verses which he called Songs.

Cavafy's windows display a powerful anguish due to deep solitude and isolation, ending in unawareness and blindness. Reflection and symbolism prevail conveying inevitability. Direness and obscurity, of the 'dark' and 'empty', together with the impossibility of finding an exit disclose the idea of an endless torment of 'I circle back and forth trying to find the windows'. The antithesis is clear in the ambivalence of wishing and fearing the 'tyranny of the light'. The poem communicates destiny's burden, helplessness, and impotence that perhaps 'windows aren't there to be found'. There is no escape. Bitterness is hard and inclement is fate. This time,

6. C. P. Cavafy, Collected Poems. Revised Edition. Translated by Edmund Keely \& Philip Sherrard; Edited by George Savidis. Princeton University Press, Princeton, New Jersey, 1992, p. 15. the first person ' $\mathrm{I}$ ' is used. However, the poet is less a subject that acts than one than suffers the effect of an impersonal destiny. Cavafy is very economical with words, he carves his verses in short and bare clauses -clauses which are extremely elaborated, thought and corrected.

\section{Present tense and existence}

Proverbs and Song-Verse 34-VI

Wayfarer, the only way

is your footsteps, there is no other.

Wayfarer, there is no way,

you make the way as you go.

As you go, you make the way and stopping to look behind,

you see the path that your feet will never travel again.

Wayfarer, there is no way-

only foam trails in the sea.

Proverb and Song Verse 34-IX ${ }^{8}$

All passes and all remains;

but our lot is to pass,

to pass making roads,

making roads in the sea.

Candles $^{9}$

Days to come stand in front of us like a row of lighted candlesgolden, warm, and vivid candles.

Days gone by fall behind us, a gloomy line of snuffed-out candles; the nearest are smoking still, cold, melted, and bent.

I don't want to look at them: their shape saddens me, and it saddens me to remember their original light.

I look ahead at my lighted candles.

I don't want to turn for fear of seeing, terrified, how quickly that dark line gets longer, how quickly the snuffed-out candles proliferate.

Existence is sung by Machado in a harmonious march cadence. The repetition punctuates the flow. We are touched by the modulation and evolution of the poem that invite us

7. Antonio Machado, Selected Poems. Translated by Alan S. Trueblood. Harvard University Press, Cambridge, Massachusetts, 1997, p. 143.

8. Antonio Machado, Selected Poems. Translated by Alan S. Trueblood. Harvard University Press, Cambridge, Massachusetts, 1997, p. 145.

9. C. P. Cavafy, Collected Poems. Revised Edition. Translated by Edmund Keely \& Philip Sherrard; Edited by George Savidis. Princeton University Press, Princeton, New Jersey, 1992, p. 9. 
to accompany the wayfarer's steps in 'making roads'. The action time is the present 'all passes and all remains'. The verb sequence organizes and sustains the image - an image like a moving picture that captivates by its musicality, transmits looseness and softness, and conveys a smoothness that life may have. There is no feeling of remorse or grief when looking back and seeing what was left behind, since 'our lot is to pass'.

In Cavafy the straight line dominates the portrait - a global picture shaped with depth, perspective, with the prevalence of form. However, there is the participation of claireobscure nuances that compose a pictorial scene of a candle procession evoking passed years and suggesting future ones. The symbolism of life-span looks like a black and white photo. Anguish and affliction are induced by the interplay of 'lighted' and 'snuffed-out' candles. The contrast of 'warm' and 'cold', 'vivid' and 'melted', in spite of its sensorial features, appeals more to thinking than to feeling, since the analogy of life and death moments is used to illustrate mortality. The present time is absent, pass and future predominate. Movement is of an inanimate nature, result of an articulation of contrasts: 'lighted and burned candles' - a nonlived movement; thus the antithesis, typical of the rational style.

\section{Past and present tenses: memories}

Poem $4^{10}$

I follow the songs

of children at play

intoning old airs

in their singing games,

pouring forth in song

their fondest dreams,

the way stone fountains

pour waters forth:

in a monotone

of age-old laughter

empty of joy,

in the mournful tones,

of sadness lingering,

bitterness gone,

the sadness of love

in ancient legend.

Voices $^{11}$

Voices loved and idealised.

of those who have died, or of those

lost for us like the dead.

10. Antonio Machado, Selected Poems. Translated by Alan S. Trueblood. Harvard University Press, Cambridge, Massachusetts, 1997, p. 77.

11. C. P. Cavafy, Collected Poems. Revised Edition. Translated by Edmund Keely \& Philip Sherrard; Edited by George Savidis. Princeton University Press, Princeton, New Jersey, 1992, p. 20.
Sometimes they speak to us in dreams; sometimes deep in thought the mind hears them.

And with their sound for a moment return

sounds from our life's first poetry-

like music at night, distant, fading away.

Both poets appeal to memories by the concurrence of listening and sounds.

Machado calls for the 'songs of at play intoning old airs', Cavafy for the 'voices, loved and idealized of those who have died'. It is the opposition between life and death, motion and passivity, party and person, present and past. Both of them deliver a dream, one talks of 'pouring forth in song their fondest dreams', the other of 'speaking to us in dreams'; one turns to external world, the other retracts to himself.

Machado communicates his nostalgia through the melodious sonority of his verses, and the harmonious flow of his clauses. The children's movements of playing their 'singing games' arise a round and turning image, like a Gestalt pregnancy, and creates a shift that gives structure to the poem - a shift toward the past through a move of redeeming it. The 'age-old laughter' and the 'sadness of love in ancient legend' evoke sweet souvenirs found in memories. Therefore, the past experience is turned alive in the present. The long stanza is composed by one single clause, in a very sensorial way.

Cavafy expresses detachment from existence, distance that separates live form death. 'Voices idealized' inscribes the poet's need for perfection, ideal achieved by those not present. Characters of another time are evoked through sounds 'like music at night, distant, fading away'. However, those who left are brought back by the mediation of voices, and dreams, from the depth of the mind, such as the concurrence of reason and spirit. As always, short clauses are linearly enchained in an economy of words.

\section{Verb cadences, allegories and life journey}

Solitudes II $^{12}$

I've made my way on many roads,

I've opened paths by scores;

I must have sailed a hundred seas,

Moored on a hundred shores.

I've caravans of sadness seen

In every place I've been,

Drunk with black shadow, very proud

And melancholy men,

And offstage pedants who just watch,

Say nothing and yet think

12. Antonio Machado, Roads dreamed clear afternoons. An anthology of the poetry of Antonio Machado. Translated into English verse by Carl W. Cook. Spanish Literature Publications Company. York, South Carolina, 1994, p. 11. 
They know it all, because they don't

Wine of the taverns drink.

Bad people who walk here and there,

The whole earth making stink ...

And everywhere I've people seen

Who either dance or play,

Whenever the can, and on small plots

Of land they slave away.

They never, coming to a place,

Ask where it is they are.

They ride upon an old mule's back

When they are traveling far,

And haste they never come to know,

Not even days for fun.

Where there is wine they drink their wine;

Cool water, when there's none.

They are good people who work hard,

Live, dream, and pass on by,

And on a day like other days,

Beneath the ground they lie.

Ithaka $^{13}$

As you set out for Ithaka

hope the voyage is a long one,

full of adventure, full of discovery.

Laistrygonians, Cyclops,

angry Poseidon — don't be afraid of them:

you'll never find things like that on your way

as long as you keep your thoughts raised high,

as long as a rare excitement

stirs your spirit and your body.

Laistrygonians and Cyclops,

wild Poseidon-you won't encounter them

unless you bring them along inside your soul,

unless your soul sets them up in front of you.

Hope your voyage is a long one.

May there be many a summer morning when,

with what pleasure, what joy,

you come into harbors seen for the first time;

may you stop at Phoenician trading stations

to buy fine things,

mother of pearl and coral, amber and ebony,

sensual perfume of every kind-

as many sensual perfumes as you can;

and may you visit many Egyptian cities

to gather stores of knowledge from their scholars.

13. C. P. Cavafy, Collected Poems. Revised Edition. Translated by Edmund Keely \& Philip Sherrard; Edited by George Savidis. Princeton University Press, Princeton, New Jersey, 1992, p. 36.
Keep Ithaka always in your mind.

Arriving there is what you're destined for.

But do not hurry the journey at all.

Better if it lasts for years,

so you are old by the time you reach the island, wealthy with all you've gained on the way, not expecting Ithaka to make you rich.

Ithaka gave you the marvellous journey.

Without her you would not have set out.

She has nothing left to give you now.

And if you find her poor, Ithaka won't have fooled you.

Wise as you will have become, so full of experience, you'll have understood by then what these Ithakas mean.

In conclusion, two of the most beautiful poems of Machado and Cavafy. Both summon man's venture during existence, his life's trajectory; our own journey.

Machado and his roads and paths. All in the poem is motion and animation; a rhythmic progression that invites us to follow the poet in his paths. The verb cadence of: 'make', 'open', 'sail', 'moor', 'drink', 'walk', 'dance', 'play', 'slave away', 'come', 'ride', 'travel', 'work', 'live', 'dream', and 'pass on', points the tempo. The verse sonority resounds in us - the vivacious sensoriality that gives the impression that the poet and we stride side by side in a strong empathic movement. This sensoriality engenders a cinematography picture full of vitality. More than ever, it is in this poem that Machado uses verbs as liaison and support elements for the stanzas.

In Ithaka Cavafy appeals to Ulysses' legend and his Odyssey as life symbolism. The hero and his expedition that face the inner and outer dangers and threads - it is the allegory of internal and external ghosts that one has to face. Ithaka symbolizes the perfection never achieved and the true meaning of man's eternal search is not found when the voyage is over, but in the voyage itself. Ithaka has offered a unique trip, one of knowledge, learning, wisdom, nothing else. Cavafy is reason, abstraction and symbolism; he mentions 'thinking', 'spirit', 'soul', 'mind', and 'aim'.

\section{Conclusion}

How universal and ordinary are the themes treated by both poets! Preoccupations of a person and of all people. Each poet with his style, his way of expressing himself, his language, and his writing - such different personalities! Each one organizing his personal particularities through the recreation of his inner world, his 'lived experience.' Each one employing his talent in order to overcome his idiosyncrasies. Summarizing, it is the appeal to creativity as a way of conquering personal vicissitudes; creativity as a way of the survival of the spirit and the immortality of the soul. To us both poets are very alive. 


\section{References}

Ganidel, G. (1960). Etude sur le langage de Flaubert et de Giraudoux. Cahiers du Groupe Françoise Minkowska, III,1:3-10.

Helman, Z. (1959). Rorschach et électroencéphalogramme chez l'enfant épileptique. Paris: Presses Universitaires de France.

Helman, Z. (1984). Structural Psychopathology. Structure and Evolution. New York: Brunner \& Mazel.

Cavafy, C. P. (1992). Collected Poems. Revised Edition. Translated by Edmund Keely \& Philip Sherrard; Edited by George Savidis.Princeto. New Jersey: Princeton University Press.

Machado, A. (1983). Poesias. Buenos Aires: Losada.

Machado, A. (1994). Roads dreamed clear afternoons. An anthology of the poetry of Antonio Machado. Translated into English verse by Carl W. Cook. York. South Carolina: Spanish Literature Publications Company.

Machado, A. (1997). Selected Poems. Translated by Alan S.
Trueblood. Cambridge: Harvard University Press.

Minkowska, F. (1949). De Van Gogh et Seurat aux dessins d'enfants. Paris: Presses du Temps Présent.

Minkowska, F. (1956). Le Rorschach, à la recherche du monde des formes. Paris: Desclée de Brower.

Minkowski, E. (1924, 1965). Les schizophrènes peints par euxmêmes. Cahiers du Groupe Françoise Minkowska, VIII,3:1718.

Rispal, Y. (1962). Le monde de Lautréamont à travers l'étude du langage. Cahiers du Groupe Françoise Minkowska, V, 3:9-50.

Yazigi, L. (1998). Ensayo fenomenológico sobre Konstantino Kavafis. Anuario de la Psicologia del Self. 3:169-179.

Yourcenar, M. (1978). Présentation critique de Constantin Cavafy, In. Constantin Cavafy: Poèmes. Traduction de Marguerite Yourcenar et Constantin Dimaras. Paris: Gallimard.

Recebido em 10/08/2002

Primeira decisão editorial em 20/09/2002

Aceito em 07/11/2002 